\title{
Analisis Perkembangan Ekspor Impor Barang Ekonomi di Provinsi Sumatera Utara
}

\author{
Sari Wulandari, ${ }^{1, *} \&$ Anggia Sari Lubis ${ }^{2}$ \\ ${ }^{1,2}$ Fakultas Ekonomi Universitas Muslim Nusantara Al Washliyah, Medan, Indonesia \\ *Email: wulanda21.wd@gmail.com
}

\begin{abstract}
This study aims to determine the development of exports and imports of North Sumatra Province through export and import value indicators, balance sheets and trade ratios. Data analysis techniques in research are qualitative descriptive data analysis. The data sources in this study are secondary data downloaded through www.bps.go.id, especially data on exports and imports and the trade balance of economic goods groups in North Sumatra Province. The results showed that there was an increase and improvement that could be seen from the increase in the volume and value of exports of economic goods groups, a decrease in the volume and value of imports of economic goods groups as well as an increase in foreign trade ratios and a trade balance that showed positive foreign economic goods group controlled by exports.
\end{abstract}

\begin{abstract}
Abstraksi: Penelitian ini bertujuan untuk mengetahui perkembangan ekspor dan impor Provinsi Sumatera Utara melalui indikator nilai ekspor dan impor, neraca dan rasio perdagangan. Teknik analisis data dalam penelitian adalah analisis data deskriptif kualitatif. Sumber data dalam penelitian ini adalah data sekunder yang diunduh melalui www.bps.go.id, terutama data ekspor dan impor dan neraca perdagangan kelompok barang ekonomi di Provinsi Sumatera Utara. Hasil penelitian menunjukkan bahwa terdapat suatu peningkatan yang dapat dilihat dari peningkatan volume dan nilai ekspor kelompok barang ekonomi, penurunan volume dan nilai impor kelompok barang ekonomi, serta peningkatan perdagangan luar negeri rasio dan neraca perdagangan yang menunjukkan kelompok barang ekonomi asing yang positif dikendalikan oleh ekspor.
\end{abstract}

Keywords: export; import; economic growth

\section{Pendahuluan}

Perkembangan Ekonomi suatu Negara ditandai dengan peningkatan pengiriman barang, baik itu yang berasal dari dalam negeri keluar negeri ataupun sebaliknya. Hal ini merupakan salah satu pendorong utama dalam pertumbuhan ekonomi Negara tersebut.

Perdagangan merupakan salah satu alternatif untuk mencapai suatu perkembangan terutama apabila mencapai skala internasional yaitu perdagangan internasional. Dalam perdagangan internasional kegiatan jual beli dinamakan transaksi ekspor-impor. Transaksi ekspor impor adalah transaksi juali beli produk antar pengusaha yang bertempat tinggal di negaranegara yang berbeda.

Salah satu pencatatan transaksi ekonomi adalah neraca pembayaran. Neraca pembayaran sebuah negara dikatakan surplus apabila terdapat kelebihan dana perdagangan dan investasi dibandingkan kewajibankewajiban yang dibayarkan kepada negara sedangkan dikatakan defisit apabila impor lebih besar dari pada ekspor. Keadaan neraca pembayaran yang surplus atau defisit dapat mempengaruhi pertumbuhan ekonomi di suatu negara.

Ekspor adalah menjual barang dari dalam negeri keluar peredaran Republik Indonesia dan barang yang dijual tersebut harus dilaporkan kepada Direktoral Jendral Bea dan Cukai Departemen Keuangan, sedangkan impor adalah membeli barang dari luar negeri ke dalam peredaran Republik Indonesia dan barang yang dibeli tersebut harus dilaporkan kepada Direktorat Jendral Bea dan Cukai Departemen Keuangan (Hamdani dan Haikal, 2018).

Untuk melihat perkembangan atas ekspor di Provinsi Sumatera Utara dapat dilihat pada Gambar 1 . 


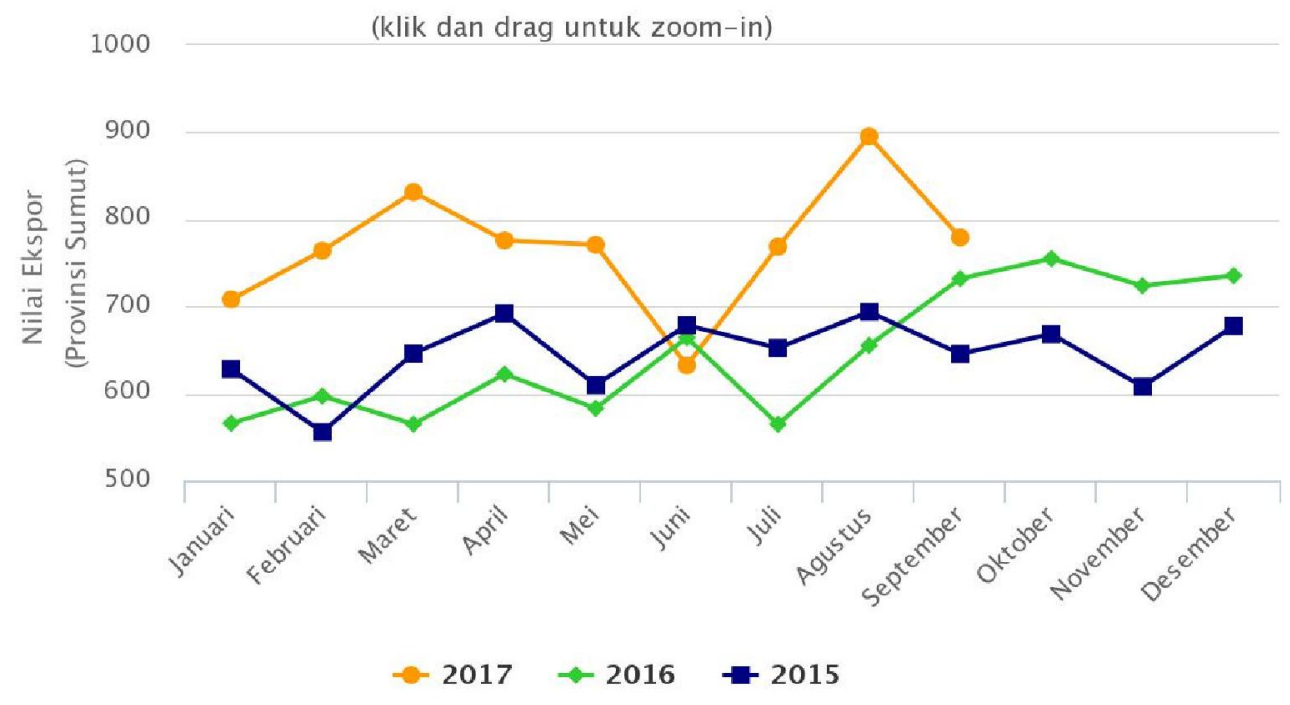

Gambar 1. Perkembangan Ekspor Provinsi Sumatera Utara

Sumber: BPS Sumut (2018)

Gambar 1 menunjukkan bahwa perkembangan ekspor Provinsi Sumatera Utara cenderung berfluktuatif pada tiga tahun terakhir (2015-2017). Terlihat pada tahun 2016 mengalami penurunan, namun kembali naik pada tahun 2017.

\section{Kajian Teori}

\section{Teori Keunggulan Komparatif}

Teori pertama mengenai ekspor yang dikemukakan para ahli ialah teori keunggulan komparatif. Teori ini dikemukakan oleh David Ricardo. Dalam teori ini, ia menyatakan bahwa perdagangan internasional atau ekspor dapat terjadi apabila terdapat perbedaan keunggulan komparatif dari setiap negara. Keunggulan komparatif ini dapat dicapai apabila sebuah negara mampu memproduksi sejumlah barang dengan volume besar namun dengan biaya yang lebih kecil dibandingkan dengan negara lain. Teori ini memandang bahwa sebuah negara dapat menghasilkan banyak keuntungan dengan menjual keunggulan komparatif yang dimilikinya ke negara lain. Selain itu, pendapatan yang diperoleh juga dapat berasal dari spesialisasi produksi barang atau jasa yang memiliki produktifitas dan efisiensi tinggi. Dalam hal ini, tentunya faktor utama penentu adalah jumlah Sumber daya alam dan sumber daya manusia yang mampu mengolah dengan biaya kecil namun menghasilkan volume yang lebih besar ketimbang negara lain.

\section{Teori Ekspor}

Ekspor dapat diartikan sebagai pengiriman dan penjualan barang-barang dari dalam negeri ke luar negeri. Menurut Murni dalam Farina dan Husaini (2017), ekspor adalah suatu kegiatan ekonomi menjual produk dalam negeri ke pasar di luar negeri. Keuntungan melakukan ekspor menurut Sukirno dalam Farina dan Husaini (2017) adalah dapat memperluas pasar, menambah devisa negara, memperluas lapangan kerja.

\section{Teori Impor}

Impor merupakan pembelian dan pemasukan barang dari luar ke dalam negeri. Murni dalam Farina dan Husaini (2017) menyatakan bahwa impor merupakan kegiatan ekonomi membeli produk luar negeri untuk keperluan atau dipasarkan di dalam negeri. Kecenderungan kegiatan impor yang besar tidak sepenuhnya buruk bagi sebuah negara karena impor juga akan merangsang kegiatan investasi, apabila barang yang diimpor merupakan barang modal, barang mentah, barang setengah jadi untuk keperluan perindustrian. Pengembangan industri subtitusi impor di 
dalam negeri harus sejalan dengan penggalakan ekspor" (Arsyad dalam Ferina dan Husaini, 2017).

Ekspor dan impor suatu negara terjadi karena adanya manfaat yang diperoleh akibat transaksi perdagangan luar negeri. Perdagangan juga dapat memperbesar kapasitas konsumsi suatu negara serta membantu berbagai usaha untuk melakukan pembangunan dan meningkatkan peranan sektor yang mempunyai keunggulan komparatif karena efesiensi dalam faktor produksi.

\section{Metode}

Metode pengumpulan data yang digunakan pada penelitian yaitu dengan meminta data dari instansi-instansi terkait, baik pemerintah maupun swasta yang menangani kegiatan ekspor impor barang ekonomi di Sumatera Utara meliputi gambaran pelaksanaan ekspor impor serta kebijakan pemerintah dalam pelaksanaan ekspor impor, selain itu juga dipelajari dokumen atau laporan mengenai volume dan nilai ekspor impor barang ekonomi di Sumatera Utara yang bisa diunduh melalui data dari BPS (Laporan Ekspor Impor Barang Ekonomi Provinsi Sumatera Utara).

Jenis penelitian ini adalah penelitian deskriptif, yaitu suatu jenis penelitian yang bertujuan memberikan gambaran atau penjelasan mengenai perkembangan ekspor impor kelompok barang ekonomi di Provinsi Sumatera Utara.

Sumber data dalam penelitian ini menggunakan: (1) Data kualitatif: yaitu data yang berupa kata, kalimat, gambar dan lain sebagainya yang diperoleh dalam penelitian baik dari hasil wawancara maupun dokumentasi, seperti kebijakan pemerintah tentang eskpor impor; (2) Data kuantitatif: yaitu data yang berupa angka-angka data ekspor dan impor barang ekonomi Provinsi Sumatera Utara. Sumber data yang digunakan pada penelitian ini adalah data primer dan data sekunder yaitu data yang diperoleh dari insatansi-instansi terkait, Biro Pusat Statistik, pemerintah setempat dan lain-lain yang telah tersedia.

Analisa data yang digunakan pada penelitian ini adalah analisis deskriptif dengan melihat perkembangan volume dan nilai ekspor impor barang ekonomi di Provinsi Sumatera Utara serta neraca ekspor impor (Sugiyono, 2014). Selanjutnya dilakukan pula analisis menurut widodo dalam Ridwan dkk, 2010) sebagai berikut:

Nilai ekspor barang ekonomi = nilai ekspor barang modal + nilai ekspor bahan baku/penolong + nilai ekspor barang konsumsi.

Nilai impor barang ekonomi $=$ nilai impor barang modal + nilai impor bahan baku/penolong + nilai impor barang konsumsi.

Neraca perdagangan $=$ Nilai ekspor barang ekonomi - Nilai impor barang ekonomi.

Rasio perdagangan $=$ (nilai ekspor barang ekonomi - nilai impor barang ekonomi) : (nilai ekspor barang ekonomi + nilai impor barang ekonomi)

Jika nilai rasio positif $(+)$ berarti neraca perdagangan dikuasai oleh ekspor. Jika nilai rasio negatif (-) berarti neraca perdagangan dikuasai oleh impor.

\section{Hasil}

Perkembangan ekspor dan impor barang ekonomi

Ekspor impor adalah suatu kegiatan bisnis yang berskala internasional yang sangat berperan penting dalam menyokong pertumbuhan ekonomi suatu negara maupun wilayah. Dalam hal ini kondisi ekonomi suatu negara sangat mempengaruhi aktivitas bisnis internasional atau ekspor impor. Dikatakan demikian karena apabila kondisi ekonomi suatu negara dalam keadaan baik maka akan berdampak positif pada kegiatan bisnis yang berskala internasional termasuk ekspor impor barang ekonomi. 
Tabel 1. Perkembangan Ekspor Kelompok Barang Ekonomi Provinsi Sumatera Utara 2013-2017

\begin{tabular}{|c|c|c|c|c|c|c|c|c|}
\hline \multirow[b]{2}{*}{ Tahun } & \multicolumn{3}{|c|}{ Berat Bersih (ton) } & \multicolumn{5}{|c|}{ Nilai FOB (000 US\$) } \\
\hline & $\begin{array}{l}\text { Barang } \\
\text { Modal }\end{array}$ & $\begin{array}{c}\text { Bahan } \\
\text { Baku/ } \\
\text { Penolong }\end{array}$ & $\begin{array}{c}\text { Barang } \\
\text { Konsumsi }\end{array}$ & Jumlah & $\begin{array}{l}\text { Barang } \\
\text { Modal }\end{array}$ & $\begin{array}{c}\text { Bahan } \\
\text { Baku/ } \\
\text { Penolong }\end{array}$ & $\begin{array}{c}\text { Barang } \\
\text { Konsumsi }\end{array}$ & Jumlah \\
\hline 2013 & 43.639 & 7.147 .823 & 2.084 .879 & 9.276 .341 & 125.466 & 6.895 .103 & 77.436 & 9.598 .005 \\
\hline 2014 & 40.832 & 6.981 .129 & 2.065 .565 & 9.087 .526 & 126.522 & 6.374 .978 & 2.859 .612 & 9.361 .112 \\
\hline 2015 & 35.689 & 6.945 .218 & 2.027 .613 & 9.008 .520 & 102.934 & 5.125 .959 & 2.523 .895 & 7.752 .788 \\
\hline 2016 & 50.512 & 6.390 .718 & 1.946 .127 & 8.387 .357 & 206.445 & 5.123 .225 & 2.441 .072 & 7.770 .742 \\
\hline 2017 & 12.065 & 7.972 .439 & 997.266 & 8.981 .770 & 35.928 & 7.364 .944 & 1.824 .414 & 9.225 .286 \\
\hline
\end{tabular}

Sumber: BPS Provinsi Sumatera Utara (2018)

Provinsi Sumatera utara adalah salah satu provinsi di Indonesia yang melaksanakan kegiatan ekspor impor barang ekonomi. Walaupun barang ekonomi bukan merupakan komoditas utama di Provinsi Sumatera Utara akan tetapi komoditas barang ekonomi tetap memberikan kontribusi pada pertumbuhan ekonomi di Sumatera Utara.

\section{Perkembangan Ekspor Barang Ekonomi}

Barang Ekonomi yang terdiri dari barang modal, bahan baku/penolong dan barang konsumsi merupakan beberapa barang yang diekspor Sumatera Utara. Barang-barang tersebut merupakan barang kebutuhan yang cukup penting dalam pemenuhan kebutuhan hidup masyarakat. Untuk lebih jelasnya dapat dilihat pada tabel 1.

Tabel 1 menunjukkan bahwa terjadi penurunan volume ekspor kelompok barang ekonomi dalam kurun waktu lima tahun (2013-2017). Tahun 2013 volume ekspor barang ekonomi sebesar 9.276.341 ton dengan nilai ekspor sebesar 9.598.005 US\$ sedangkan tahun 2014 volume ekspor sebesar 9.087.526 dengan nilai ekspor sebesar 9.361.112US\$. Nilai-nilai tersebut menunjukkan bahwa volume dan nilai ekspor barang ekonomi untuk tahun 2014 turun sekitar 2\% dibandingkan dengan volume ekspor tahun 2013. Pada tahun 2015 dan 2016 volume ekspor barang ekonomi juga mengalami penurunan tetapi hanya sebesar $0,8 \%$ dan nilai jualnya pun menurun sebesar $22 \%$. Pada tahun 2017 untuk volume ekspor barang ekonomi mengalami kenaikan sebesar $4 \%$ dan untuk nilai jualnya pun naik sebesar $26 \%$.

\section{Perkembangan Impor Barang Ekonomi}

Impor diartikan sebagai kegiatan memasukkan barang dari suatu negara (luar negeri) kedalam wilayah pabean negara lain. Jadi selain kegiatan ekspor, untuk memenuhi kebutuhan masyarakat Sumatera Utara atas barang ekonomi, maka dilakukanlah impor dari negara lain.

Tabel 2. Perkembangan Impor Kelompok Barang Ekonomi Provinsi Sumatera Utara 2013-2017

\begin{tabular}{|c|c|c|c|c|c|c|c|c|}
\hline \multirow[b]{2}{*}{ Tahun } & \multicolumn{3}{|c|}{ Berat Bersih (ton) } & \multirow[b]{2}{*}{ Jumlah } & \multicolumn{3}{|c|}{ Nilai CIF (000 US\$) } & \multirow[b]{2}{*}{ Jumlah } \\
\hline & $\begin{array}{l}\text { Barang } \\
\text { Modal }\end{array}$ & $\begin{array}{c}\text { Bahan } \\
\text { Baku/Penolo } \\
\text { ng }\end{array}$ & $\begin{array}{r}\text { Barang } \\
\text { Konsumsi }\end{array}$ & & $\begin{array}{l}\text { Barang } \\
\text { Modal }\end{array}$ & $\begin{array}{c}\text { Bahan } \\
\text { Baku/Peno } \\
\text { long }\end{array}$ & $\begin{array}{c}\text { Barang } \\
\text { Konsumsi }\end{array}$ & \\
\hline 2013 & 281.359 & 4.887 .480 & 1.780 .284 & 6.949 .123 & 828.052 & 3.078 .517 & 1.201 .941 & 5.108 .510 \\
\hline 2014 & 310.252 & 5.074 .349 & 2.006 .708 & 7.391 .309 & 739.884 & 3.129 .763 & 1.176 .867 & 5.046 .514 \\
\hline 2015 & 207.857 & 4.816 .580 & 1.829 .297 & 6.853 .734 & 707.508 & 2.320 .331 & 960.603 & 3.988 .442 \\
\hline 2016 & 285.767 & 4.508 .806 & 2.024 .620 & 6.819 .193 & 872.093 & 1.957 .156 & 1.085 .241 & 3.914 .490 \\
\hline 2017 & 208.365 & 6.491 .243 & 339.164 & 7.038 .772 & 696.462 & 3.556 .398 & 382.949 & 4.635 .809 \\
\hline
\end{tabular}

Sumber: BPS Provinsi Sumatera Utara, 2018 
Tabel 2 menunjukkan bahwa komoditas barang ekonomi yang diimpor ke Sumatera Utara diantaranya adalah barang modal, berarti bahwa impor lebih besar dari ekspor. Dengan analisa ini maka dapat diketahui apakah suatu negara atau wilayah dikuasai

Tabel 3. Neraca ekspor impor barang ekonomi Provinsi Sumatera Utara 2013-2017

\begin{tabular}{lllllll}
\hline \multirow{2}{*}{ Tahun } & \multicolumn{2}{c}{ Volume (ton) } & \multirow{2}{*}{ Neraca } & \multicolumn{2}{c}{ Nilai (000 US\$) } & \multirow{2}{*}{ Neraca } \\
\cline { 2 - 3 } & Ekspor & Impor & & Ekspor & Impor & \\
\hline 2013 & 9.275 .890 & 6.949 .117 & 2.326 .773 & 9.598 .008 & 5.108 .510 & 4.489 .498 \\
2014 & 9.087 .526 & 7.391 .305 & 1.696 .221 & 9.361 .110 & 5.046 .514 & 4.314 .596 \\
2015 & 9.008 .520 & 6.853 .734 & 2.154 .786 & 7.752 .786 & 3.988 .440 & 3.764 .346 \\
2016 & 8.387 .357 & 6.819 .193 & 1.568 .164 & 7.770 .742 & 3.914 .490 & 3.856 .252 \\
2017 & 8.981 .772 & 7.038 .772 & 1.943 .000 & 9.225 .286 & 4.635 .808 & 4.589 .478 \\
\hline
\end{tabular}

Sumber: BPS Provinsi Sumatera Utara setelah diolah, 2018

bahan baku/penolong dan barang konsumsi. Pada tahun 2013 volume impor barang ekonomi sebesar 6.949 .123 ton dan nilai impornya sebesar 5.108.510 US\$. Pada tahun 2014 volume impor mengalami kenaikan menjadi sebesar 7.391.309 ton dengan nilai impor sebesar 5.046.514 US\$. Pada tahun 2015 volume impor mengalami penurunan sebesar 6.853 .734 dengan nilai impor sebesar 3.988.442, dan pada tahun 2016 volume impor turun menjadi sebesar 6.819.193 dengan nilai impor sebesar 3.914.490. Namun pada tahun 2017 volume impor mengalami kenaikan sebesar 7.038.772 dengan nilai impor yang juga naik sebesar 4.635.809.

Dari tabel dapat terlihat untuk volume dari tahun 2013-2017 mengalami fluktuasi, namun untuk nilai impornya mengalami penurunan. Hal ini disebabkan oleh kondisi perekonomian dunia, kondisi nilai tukar rupiah, serta kebijakan-kebijakan pemerintah yang berkaitan dengan impor barang ekonomi.

\section{Neraca ekspor impor barang ekonomi}

Neraca perdagangan ekspor impor menunjukkan selisih antara volume ekspor dengan volume impor dan selisih antara nilai ekspor dengan nilai impor. Jika nilainya positif maka itu menunjukkan bahwa nilai ekspor lebih besar daripada nilai impor, begitu pula sebaliknya jika nilainya negatif oleh ekspor atau impor. Berikut adalah Neraca Perdagangan ekspor impor barang ekonomi Provinsi Sumatera Utara tahun 2013 sampai dengan 2017 dapat dilihat pada tabel 3 .

Tabel 3 menunjukkan bahwa neraca perdagangan ekspor impor barang ekonomi Provinsi Sumatera utara dari tahun 2013 sampai dengan 2017 cenderung berfluktuasi. Neraca perdagangan dari segi volume ekspor impor menunjukkan pada tahun 2013 sebesar 2.326.773 ton, dimana terlihat bahwa volume perdagangan luar negeri barang ekonomi Provinsi Sumatera Utara dikuasai oleh ekspor. Selanjutnya nilai neraca perdagangan luar negeri barang ekonomi provinsi Sumatera Utara dari tahun 2014 sampai dengan 2017 tetap berada diangka yang positif yang berarti bahwa nilai perdagangan luar negeri barang ekonomi Provinsi Sumatera Utara dikuasai oleh ekspor. Hal ini disebabkan karena harga barang ekonomi yang diekspor oleh provinsi Sumatera Utara lebih tinggi jika dibandingkan dengan harga barang komoditi yang diimpor.

\section{Rasio Perdagangan}

Rasio perdagangan menunjukkan besarnya selisih antara nilai ekspor dengan nilai impor terhadap total perdagangan dunia pada suatu negara atau wilayah. Besarnya rasio perdagangan ekspor impor kelompok barang ekonomi provinsi sumatera utara dari 
tahun 2013 sampai dengan 2017 dapat dilihat pada tabel 4 .

\begin{tabular}{|c|c|c|c|}
\hline Tahun & $\begin{array}{c}\text { Nilai } \\
\text { Ekspor - } \\
\text { Impor } \\
\text { (US\$) }\end{array}$ & $\begin{array}{c}\text { Nilai } \\
\text { Ekspor + } \\
\text { Impor } \\
\text { (US\$) }\end{array}$ & Rasio \\
\hline 2013 & 4.489 .498 & 14.706 .518 & 1,87 \\
\hline 2014 & 4.314 .596 & 14.407 .624 & 1,85 \\
\hline 2015 & 3.764 .346 & 11.741 .226 & 1,94 \\
\hline 2016 & 3.856 .252 & 11.685 .232 & 1,98 \\
\hline 2017 & 4.589 .478 & 13.861 .094 & 1,99 \\
\hline
\end{tabular}

Sumber: BPS Provinsi Sumatera Utara, diolah (2018)

Tabel 4 menunjukkan bahwa rasio perdagangan ekspor impor kelompok barang ekonomi provinsi sumatera utara dari tahun 2013 sampai dengan 2017 cenderung meningkat setiap tahunnya. Rasio perdagangan ekspor impor kelompok barang ekonomi provinsi sumatera utara tertinggi pada tahun 2017 yaitu sebesar 1,99 sedangkan rasio perdagangan ekspor impor kelompok barang ekonomi provinsi sumatera utara terendah pada tahun 2013 yaitu sebesar 1,87. Hal ini menunjukkan bahwa rasio perdagangan ekspor impor kelompok barang ekonomi provinsi Sumatera Utara dari tahun 2013 sampai dengan 2017 cenderung mengalami peningkatan.

\section{Pembahasan}

Dari data yang diperoleh memperlihatkan bahwa secara keseluruhan perkembangan ekspor impor kelompok barang ekonomi provinsi Sumatera Utara dari tahun 2013 sampai dengan 2017 cenderung mengalami peningkatan dan perbaikan. Hal ini terlihat dari beberapa indikator seperti peningkatan volume dan nilai ekspor, penurunan volume dan nilai impor, peningkatan jumlah barang ekonomi yang diekspor, dan neraca perdagangan yang menunjukkan nilai yang positif. Hal tersebut menunjukkan bahwa perdagangan internasional kelompok barang ekonomi provinsi Sumatera Utara dikuasai oleh kegiatan ekspor, serta rasio perdagangan yang terus mengalami peningkatan yang menunjukkan bahwa semakin membaiknya perdagangan luar negeri atas ekspor impor kelompok barang ekonomi di provinsi Sumatera Utara.

\section{Kesimpulan}

Berdasarkan hasil penelitian dan pembahasan, maka peneliti menarik kesimpulan diantaranya: (1) Kinerja ekspor impor kelompok barang ekonomi Provinsi Sumatera Utara menunjukkan suatu peningkatan dan perbaikan yang bisa dilihat dari peningkatan volume dan nilai ekspor kelompok barang ekonomi, penurunan volume dan nilai impor kelompok barang ekonomi serta rasio perdagangan luar negeri yang cenderung mengalami peningkatan; (2) Neraca perdagangan menunjukkan nilai yang positif yang berarti perdagangan luar negeri kelompok barang ekonomi dikuasai oleh ekspor.

\section{Daftar Referensi}

Farina, Fenin dan Achmad Husaini. (2017). Pengaruh Dampak Perkembangan Tingkat Empor dan impor Terhadap Nilai Tukar Negara ASEAN Per-Dollar Amerika Serikat (Studi Pada International Trade Center Periode Tahun 2013-2015). Jurnal Administrasi Bisnis, Vol. 50 No. 6.

Hamdani \& Haikal. (2018). Seluk Beluk Perdagangan Ekspor Impor. Cetakan kelima Jilid kedua. Bushindo: Jakarta.

Ridwan, M. I.M. Saleh, A. Fitriani. (2010). Analisis Kinerja Ekspor Impor Komoditi Peternakan di Sulawesi Utara. JITP, Vol. 1 No. 1.

Sugiyono. (2014). Metode Penelitian Manajemen. Alfabeta: Jakarta.

(2018). Sumut Dalam Angka 2018. BPS Sumatera Utara. 